\title{
The Effect of Financial Development on Productivity, Corporate Tax, Foreign Reserve \& Export Vector Autoregressive (Var) Model Approach Case Study on Ireland
}

Abraham Zewdu Ararso ( $\sim$ abraham6282@gmail.com )

Waseda University

\section{Research}

Keywords: Augmented Dickey fuller test, Corporate tax, Variance decomposition, Foreign Reserve, Financial Development, Ireland, Granger causality test, Impulse response function, OECD, Vector autoregressive (VAR)

Posted Date: January 21st, 2021

DOl: https://doi.org/10.21203/rs.3.rs-150322/v1

License: (c) (i) This work is licensed under a Creative Commons Attribution 4.0 International License. Read Full License 
THE EFFECT OF FINANCIAL DEVELOPMENT ON PRODUCTIVITY CORPORATE TAX, FOREIGN RESERVE \& EXPORT

VECTOR AUTOREGRESSIVE (VAR) MODEL APPROACH

CASE STUDY ON IRELAND

Abraham Zewdu Ararso

January, 2021 


\begin{abstract}
The development financial sector plays indispensable role in accelerating economic growth and improving countries welfare system. Robust financial sector can keep the momentum of economic growth with providing substantial financial support and preserving macroeconomic balance. Given the importance of this sector, this research tried to evaluate the role of Irish financial development on productivity, corporate tax, foreign reserve and export. The research comprises a time period between 1980 until 2016 and used Vector autoregressive (VAR) model. Financial development consists of advancement both in financial institutions as well as in financial markets structure of Ireland. The estimation consists of granger causality test, impulse response estimation and variance decomposition along with VAR estimation result. VAR estimation revealed that financial development caused significant positive effect on Ireland export performance in the short run. Conversely, financial development doesn't have significant effect on Ireland productivity level, foreign reserve, and corporate tax in the short run. The Granger causality test for the study variables indicates that corporate tax rate in Ireland can cause financial development in the short run, while the remaining variables can't cause effect on financial development in the short run. The granger causality Wald tests also demonstrates that Irish financial development and productivity can unilaterally cause change in the level of Ireland export performance in the short run. The variance decomposition estimation revealed that financial development is strongly exogenous both in the short run and long run. This indicates that financial development is weak in predicting the fluctuation of productivity, foreign reserve, and corporate tax. Nevertheless, financial development is endogenous both in the short and long run in predicting the fluctuation of Ireland export.
\end{abstract}

Keywords: Augmented Dickey fuller test, Corporate tax, Variance decomposition, Foreign Reserve, Financial Development, Ireland, Granger causality test, Impulse response function, OECD, Vector autoregressive (VAR), 


\section{Introductions}

Ireland is one the fastest growing economies in the EU and among those countries that have made stride to build robust economy within OECD member states. Irish economy is knowledge economy, primarily focused on services into high-tech, life sciences, financial services and agribusiness including agrifood. The vigorous expansion of output, export and employment made economists to denote Ireland as 'Celtic Tiger'.

The Irish economy shows robust growth between 1993 until 2007. However, in the aftermath of the financial crisis the Irish economy exhibit very severe recession with low GDP growth and high unemployment. Nevertheless, the country has mitigated the macroeconomic shock on public finances, banking sector and property market sectors. Moreover, the country focused on boosting export as a primary way to consolidate the economy. Consequently, the Irish economy was able to rebound strongly over 2013-2017, with scoring aggregate growth rate of 4.4 percent. The rebound in the economy was accelerated with the expansion on investment and retail spending. As a result, unemployment rate considerably fell from 16\% in 2012 to below 6\% in 2018 and the budget deficit has swiftly declined (Mangan, 2018).

During the 2008 financial crisis, the Irish financial system was strongly stricken. The financial crisis was aggravated with the expansive domestic and cross-border banking credit. This in turn had triggered surge in real estate prices and new construction boom. Hence, the crisis has caused loss of real-estate and commercial loan which was supposed to be returned to the Irish banking system. To save these financial institutions, the government of Ireland has made substantial bailout for these financial institutions to recapitalize troubled banks and minimize risks (Schoenmaker, 2015)

Historically, the Irish economy has shown different economic spectrums over the nineteenth century, these are mainly; de-industrialization, agrarian crisis, famine and emigration, which more than halved Ireland's population(O'Malley, 1981). From 1930 until 1960's, the rising political independence has helped to pursue a strategy of protection and import substitution. In this regard, the rising protection policy has helped to increase employment in the industrial sector. Nonetheless, it becomes ineffective to solve the entrenched development problems.

In early 1960's with the intention to create export oriented economy and boost inward investment flow, the Irish government decided to fundamentally change its economic strategy from protectionism to outward orientation. Moreover, the decision to switch its economic strategy emanated from chronic balance of payment, erratic recession and emigration in the 1950's. The industrial policy that was adopted embedded financial and fiscal incentives for both local enterprises as well as for investment (O'Malley, 1992) 
From 1960 to 1987, Ireland has attained a robust economic and demographic growth. In 1960, agriculture forestry and fishing holds 37 percent of the total employment in the Irish economy. In 1987, this figure has sharply declined to 14 percent due to increase in productivity and significant economic structural transformation (NESC, 1996). The period after 1960's shows significant increase in living standard, income and wage. During 1970's due the influx of Transnational Corporations (TNCs), Ireland economy becomes highly dependent on foreign direct investment. Nonetheless, the country has experienced weak linkage between foreign owned enterprises and local firms. Ireland had made considerable trade liberalization in the late 1950s, and acceded to EU block in 1973. This two incidents has helped to change the Irish economic and landscape for the last several decades, and also ensured rapid real convergence on the momentum of economic growth (Barry, 2003)

In 1973, the heavily agriculture based Irish economy joined EU market. This measure helped Irish economy to get the untapped EU single market. Moreover, the introduction of low corporate tax rate and launching of Industrial Development Agency has helped Irish economy to get the momentum flourish. In1979, Ireland decided to join the European Exchange Rate Mechanism (ERM), with the intention to create exchange rate alignment between the Euro and Irish currency, thereby, to underpin a stable economic environment and create conducive environment for a single market.

Overall, the Irish economy performed well during the 1970's. However, from 1980 until 1987, the Irish economy faced protracted economic recession period. This recession was mainly characterized by declining employment level, falling living standard, increased public sector deficit and bouncing debt, rising balance of payment deficit. The country's debt to GNP was reached 130 percent, which makes it to reach its unprecedented level.

In the 1970's Ireland started removal of its long persisted protectionist police; thus, helped the country economy to grow faster and keeps with the remaining European countries. When Ireland joined The European Economic community in 1973 and European Monetary System in 1978 helped the county to minimize its dependence in United Kingdom (Ononugbo, 2015). In 1980's Ireland transformed its agrarian economy to a modern highly-skilled knowledge-based one driven by high-tech industries and services. Multinational corporations were attracted due to the countries and low corporation tax and high level of human capital which have made Ireland a haven to make large investment. The tripartite wage pact signed between unions, firms and Irish government helped to maintain moderate wage and minimized industrial conflict and further created conducive environment for robust competitiveness within the Irish industry

In 1990's Ireland economic growth began to grow exponentially and it surpassed most of top income European countries like UK, France and Germany in terms of GDP per capita metrics. Starting from 1990 until 1997, Ireland reached many of its EU counterparts in terms of productivity, employment and output. This economic condition was further fuelled due to the 
increasing inflow of foreign direct investment. Most of this FDI inflow to Ireland was focused on export market. In this regard, the export sector started to play significant role in the economy of Ireland through bringing remitted profit, and royalty fees and shore up Ireland to get a better current account balance.

In 1990's due to the increase in average income coupled with robust surge in domestic expenditure further precipitated construction sector to escalate. This eventually caused accelerated economic growth in what is dubbed as the Celtic Tiger period. Moreover, during this period, Ireland witnessed a sharp increase in demand for both private houses and commercial properties. From 2004 until 2007, Ireland economy is dominated by rampant property bubble. The Celtic Tiger economic period had increased the income of Irish people and triggered more people to engage in property market. The accommodative monetary policy helped Ireland to reduce its interest rate, thereby provide suitable environment for the domestic property market to be became affordable and increase its demand. During these periods, the Irish economy witnessed the emergence of a credit based property bubble (Petros, 2018).

The increased credit worthy nature of Irish financial institutions helped these financial institutions to borrow from credit bodies abroad. Furthermore, the easing of credit access at the domestic market reinforces a considerable expansion in mortgage and credit facilities issued for the construction sector.

The international financial meltdown in 2007 and 2008 caused investors to lose confidence in the Irish property market which is accompanied with a price bubble and considerable oversupply of properties. As a result, the property market started to collapse in 2008. The major characteristics of these collapses are; housing price started to decline in the aftermath of 2008 crisis and the number of people engaged in the construction sector sharply declined. Before 2008, the main drivers of Ireland economy were domestic demand which was infused by simplified credit availability and sprawling construction sector. Nevertheless, domestic demand falls sharply due to crippling housing bubble. In the aftermath of 2008 financial crisis, the export sector started to play considerable role in the Irish economy.

\section{Financial development in Ireland}

A financial sector implies a set of institutions, markets, essential financial instruments, and regulatory frameworks which allows business transactions to be made through provision of credits (World Bank, 2016). Financial sector development take place where markets financial instruments, and intermarries simplify the adverse effect of information asymmetry, transaction cost and legal enforcement, thereby shore up the indispensable functions of finical sectors within the macro economy.

A large body of literature indicates that robust financial development has considerable impact in shaping the economic development of a given country. In this regard, a strong financial development enhances economic growth via mobilizing saving and capital accumulation. 
Moreover, it helps to create information asymmetry about investment opportunities and facilitate the inflow of foreign capital, thereby, optimize the proper allocation of capital.

Ireland has a well-developed financial market. The financial sector encompass banks, investment banks, insurance companies, government sponsored enterprises, credit card companies, and consumer finance companies. The country financial sector performed quit well with registering higher margin of profitability and very robust capitalization performance, especially after their participation. The sector was also jeopardized with sustained rapid credit growth to fill the demand in mortgage credit boom in the housing market and corporate loan (IMF, 2006).

The Irish financial sector is overwhelmed by two large banking groups, these are; Allied Irish Banks and Bank of Ireland. Prior to the 1980s, Ireland financial service was underdeveloped and was regarded strange phenomenon in the country's business climate. In addition, during this period the domestic financial landscape lacks competitive nature and dominated by few financial institutions. In the 1980's capital control was lifted, this helped Irish financial institutions to expand the scope of lending activities and the development of financial market (Ononugbo, 2015).

In the 1990's, the Irish financial sector shows a dramatic growth. This was gravitated by a rapid economic growth precipitated by good domestic policies and the rising financial globalization. The increase domestic wealth increased the demand for investment in property market. The expansive financial globalization helped Irish financial intuitions to provide faster and easy domestic credit to the public. Also, the property market flourished due to the instantaneous and loose domestic credit availability.

After joining the Economic and Monetary Union, Irish economy exhibit a fall in interest rate and removal of exchange rate risk in making trade with EMU countries. In this regard, the fall in the level of interest rate intensify an increased credit demand domestically. This, in turn has triggered a property bubble to escalate in the Irish economy. Likewise, the removal of exchange rate risk further deepen cross boarder financing and opened a doer for Irish financial institution to get better access to a foreign credit. As a result, the Irish economy started to experience lending boom due to the rise in the supply and demand of credit to the domestic market.

Nevertheless, the Irish property lending system was traditional and wasn't supported with automated credit appraisal. Starting from 2003, the Irish banks leveraged their local resource with a massive borrowing from overseas credit sources. This was precipitated primarily with the international saving glut and the removal of exchange rate risk for euro borrowing. This has helped the Irish banks to increase the share of their asset in property related lending. However, in 2003, the net indebtedness of Irish financial institutions was around 10 percent of its GDP. But, this figure had further reached to 60 percent in 2008 fiscal year (Honohan, 2009).

The global financial crisis in 2008 has put a lot of pressure on the Irish economy. Most Irish financial institutions were involved on rampant property market. Consequently, Ireland economy entered chronic recession in 2008 , and subsequently the country went into economic depression in 
2009. The property market was crumbling and investors show low confidence on investing on equity in Irish banks. To sustain Irish banks, the government started to provide bailout to recapitalize its banking sector. In 2011 fiscal year the Irish government provided $€ 63$ billion or approximately 40 percent of its GDP as bailout program to recapitalize its banks (Whelan, 2013). This bailout program to underpin the banking sector has brought a huge surge in the ratio of public debt to GDP ratio.

In the aftermath of 2008 global financial crisis, the government provides significant bailout program for Irish banks. After the bailout exit, the economy started to recover and output and productivity started to revamp. In response to the banking crisis and collapse of the housing bubble the government of Ireland takes several measures like, preparing consolidate financial

regulations in the central bank, transfer large non-performing loans to NAMA ( a "Bad Bank"), implementing risk-based and intrusive control and supervision, liquidity provision and capital inject are some of the policy measures. Moreover, Ireland strengthened the deposit insurance scheme and code of conduct is prepared to minimize mortgage arrears personal bankruptcy regime (OECD, 2015).

\section{Research objective}

Given the strong financial development of Ireland among the OECD countries, the country could demonstrate a good linkage in policy effect between the Irish financial growth and the county's macro-economic stability. In this regard, this research paper is triggered to evaluate the effect of Irish financial development on productivity, output level and export of Ireland. Financial development encompasses both the growth in financial institutions and financial market.

\section{Data}

Based on conventional economic theory, this empirical research considers four major macroeconomic variables to investigate their dynamic relationship and evaluate their pragmatic interdependence with financial development within the Irish economy. The research considers data ranging from 1980 until 2016. The following are the major study variables used in this study:

i. Financial development: this variable has two major components, these are; financial institutions and financial market. These variables represent how developed financial institutions and financial markets are in terms of their depth (size and liquidity); access (ability of individuals and companies to access financial service), and efficiency (ability of institutions to provide financial service at low cost and with sustainable revenues and the level of activity of capital market) (Svirydzenka, 2016). The index is comprised of nine components; according to IMF classification the following the major sub components these are; 
FI = financial institutions, includes the following three sub components:

$F I A=$ financial institutions access $; F I D=$ financial institutions depth; FIE = financial institutions efficiency;

FM = financial markets, includes the following three sub component:

$F M A=$ financial markets access $; F M D=$ financial markets depth; FME = financial market efficiency

The financial development index is constructed with aggregation of the sub-indices into the final index

ii. Labor productivity: Labor productivity is measured in terms of GDP per hour worked. This index measures how efficiently labor input is combined with other factors of production for the production of goods and services. The ratio of labor input and output measure greatly depends on the usage of other inputs (capital, economies of scale, organizational and efficiency change, intermediate inputs, technical). ${ }^{1}$ Labor input is measured total hours worked for all persons engaged in production.it partly reflects the degree of productivity of labor in terms of workers intensity of their effort on their job and demonstrates their personal capacity to accomplish their tasks.

iii. Corporate Tax: Is a direct tax imposed on company's net income considering their business operation. The tax is levied on company's profit and collected by the government.

iv. Foreign Reserve: It's a foreign currencies held by a country's central bank. Foreign exchanges asset can comprise banknotes, deposits, bonds, treasury bills and government securities of reserve currency. Reserve assets allow a central bank to purchase the domestic currency. ${ }^{2}$

v. Export: It refers to export of goods comprises all transaction between one country and the rest of the world. In this regard, this research considers the annual export value of Ireland to the rest of the world. Data are in current U.S. dollars.

\footnotetext{
${ }^{1}$ https://www.data.oecd.org/lprdty/gdp-per-hour-worked.htm. Accessed 18 November, 2019

${ }^{2}$ Https://en.m.wikipedia.org/wiki/Foreign_exchange_reserve Accessed 20 November, 2019
} 
Descriptive statistics: Author computation

\begin{tabular}{|l|r|r|r|r|r|}
\hline & In_Financial Devt & In_Productivity & In_Corptax & In_Reserve & \multicolumn{1}{c|}{ In_Export } \\
\hline Mean & -0.398749 & 3.687843 & 0.807707 & 5.781929 & 6.449261 \\
\hline Median & -0.379797 & 3.723691 & 0.864997 & 5.822087 & 6.634105 \\
\hline Maximum & -0.236989 & 4.34715 & 1.312648 & 6.859323 & 8.197203 \\
\hline Minimum & -0.752897 & 3.038409 & 0.076961 & 4.421127 & 4.495991 \\
\hline Std. Dev. & 0.131871 & 0.379444 & 0.406601 & 0.654861 & 1.222095 \\
\hline Skewness & -0.982613 & -0.108944 & -0.54075 & -0.449942 & -0.228612 \\
\hline Kurtosis & 3.441134 & 1.843068 & 1.917578 & 2.437449 & 1.661714 \\
\hline & & & & & \\
\hline Jarque-Bera & 6.2541 & 2.136698 & 3.609475 & 1.736312 & 3.08343 \\
\hline Probability & 0.043847 & 0.343575 & 0.164518 & 0.419725 & 0.214014 \\
\hline & & & & & \\
\hline Sum & -14.7537 & 136.4502 & 29.88516 & 213.9314 & 238.6226 \\
\hline Sum Sq. Dev. & 0.626036 & 5.183195 & 5.951692 & 15.43836 & 53.76655 \\
\hline & & & & & \\
\hline Observations & 37 & 37 & & 37 & \\
\hline
\end{tabular}

Table 1: Descriptive statistics of research variables

\section{Econometric methodology}

Based on Johansson cointegration test estimation result, this research paper identifies there are no long run relationship among the variables. Hence, the study used Vector autoregressive (VAR) model.

\section{a) Overview of VAR model}

Vector autoregressive model is a special type of multivariate time series with containing a set of $\mathrm{k}$ variables which are endogenous over the same sample period $(t=1 \ldots T)$ as a linear function of only on their past values (Kunst, 2007)

A $p$-th order $V A R$, denoted $\operatorname{VAR}(p)$, is

$$
y_{t}=c+A_{1} y_{t-1}+A_{2} y_{t-2} \ldots \ldots+A_{p} y_{t-p}+e_{t}
$$

In this basic formula, $\mathrm{C}$ is an intercept of $\mathrm{K}$-vector matrix, and $\mathrm{e}_{\mathrm{t}}$ referes to multivariate white noise. Any component of the variable $K=1, \ldots, K$ depends on two parts the model. These are on the $p$ lags of itself and the other $K-1$ component of its variables. The error terms $e_{t}$ must satisfy the following basic conditions

1. $E\left(e_{t}\right)=0$ the error term need to have a zero mean 
2. $E\left(e_{t} e_{t}^{\prime}\right)=\Omega$ the error terms of the contemporaneous covariance matrix $\Omega$ (a $k \times k$ positive-semi definite matrix);

3. $E\left(e_{t} e_{t-k}^{\prime}\right)=0$ there should not be serial correlation in individual error terms and there is no correlation across time for any non-zero $k$

VAR model has important advantage over other models. Since the model involves the current and lagged values of several other timer series equations, they have the capacity to capture the movements which can't be identified by other estimation models like univariate and bivariate models (Stock and Watson, 2001).

The VAR model has multiple advantages over a single equation approach. These are; the model can handle several co-integrating vectors and endogenous variables. Moreover, VAR model can treat both I (1) and I (0) a variable in one system and it has the ability to test for weak exogeneity and parameter restrictions (M'Amanja, et.al, 2005).

\section{Concise matrix notation}

One can stack the vectors in order to write a $\operatorname{VAR}(p)$ as a stochastic matrix difference equation, with a concise matrix notation:

$$
Y=B Z+U
$$

For a general example of a VAR ( $p)$ with $k$ variables, see General matrix notation of a VAR (p).

A VAR (1) in two variables can be written in matrix form (more compact notation) as

$$
\left[\begin{array}{l}
y_{1, t} \\
y_{2, t}
\end{array}\right]=\left[\begin{array}{l}
c_{1} \\
c_{2}
\end{array}\right]+\left[\begin{array}{ll}
a_{1,1} & a_{1,2} \\
a_{2,1} & a_{2,2}
\end{array}\right]\left[\begin{array}{l}
y_{1, t-1} \\
y_{2, t-1}
\end{array}\right]+\left[\begin{array}{l}
e_{1, t} \\
e_{2, t}
\end{array}\right]
$$

(In which only a single A matrix appears because this example has a maximum lag $p$ equal to 1 ), or, equivalently, as the following system of two equations

$$
\begin{aligned}
& y_{1, t}=c_{1}+a_{1,1} y_{1, t-1}+a_{1,2} y_{2, t-1}+e_{1, t} \\
& y_{2, t}=c_{2}+a_{2,1} y_{1, t-1}+a_{2,2} y_{2, t-1}+e_{2, t}
\end{aligned}
$$

Every variable within the model has one equation. The observations of each variable are contingent on its lagged value and the lagged value of other respective variables in VAR equation.

A VAR with $p$ lags can always be equivalently rewritten as a VAR with only one lag by appropriately redefining the dependent variable. The transformation amounts to stacking the lags of the VAR $(p)$ variable in the new VAR (1) dependent variable and appending identities to complete the number of equations. The VAR basic formula can be stipulated in both the structural VAR (SVAR) model and reduced form (Zivot, 2000). 


$$
\begin{aligned}
& y_{1 t}=\gamma_{10}-b_{12} y_{2 t}+\gamma_{11} y_{1 t-1}+\gamma_{12} y_{2 t-1}+\epsilon_{1 t} \\
& y_{2 t}=\gamma_{20}-b_{21} y_{1 t}+\gamma_{21} y_{1 t-1}+\gamma_{22} y_{2 t-1}+\epsilon_{2 t}
\end{aligned}
$$

The sample consists of observations from $\mathrm{t}=1, \ldots ., \mathrm{T}$. And $\epsilon_{1 t}$ and $\epsilon_{2 t}$ are uncorrelated exogenous error tem. They are regarded as structural innovations. In matrix form, the above equation can be described as

$$
\left[\frac{1}{b_{21}} \frac{b_{12}}{1}\right]\left[\frac{y_{1 t}}{y_{21}}\right]=\left[\frac{\gamma_{10}}{\gamma_{20}}\right]+\left[\frac{\gamma_{11}}{\gamma_{21}} \frac{\gamma_{12}}{\gamma_{22}}\right]\left[\frac{y_{1 t-1}}{y_{2 t-1}}\right]+\left[\frac{\epsilon_{1 t}}{\epsilon_{21}}\right]
$$

Or

$$
\mathrm{B} y_{t}=\gamma_{0}+\Gamma_{1} y_{t-1}+\varepsilon_{t}
$$

Where,

$$
\mathrm{E}\left[e_{t} e_{t}^{\prime}\right]=D
$$

And $\mathrm{D}$ is a diagonal matrix with elements $\sigma_{1}^{2}$ and $\sigma_{2}^{2}$. In lag operator symbol, the structural Vector Autoregressive can be written as follows:

\section{b) Model Calibration}

$$
\begin{gathered}
\mathrm{B}(L)_{Y_{t}}=\gamma_{0}+\varepsilon_{t} \\
\mathrm{~B}(L)=\mathrm{B}-\Gamma_{1} L
\end{gathered}
$$

To evaluate the effect of financial development on productivity, output and export of Irish economy, the research employs multivariate time series analysis. Hence, based on the above framework of Vector Autoregressive (VAR) model, the research constructed the following VAR estimation model Ireland

$$
\begin{aligned}
& \boldsymbol{I n}_{\boldsymbol{t}}=\sigma+\sum_{i=1}^{K} \boldsymbol{\beta}_{i} \ln \boldsymbol{R}_{t-i}+\sum_{j=1}^{K} \phi_{j} \ln F D_{t-j}+\sum_{m=1}^{K} \Delta_{m} \ln P_{t-m}+\sum_{y=1}^{K} \lambda_{y} \ln E X_{t-y}+\sum_{Z=1}^{K} \pi_{z} \ln \operatorname{Ctax} x_{t-Z}+u_{1 t} \\
& \boldsymbol{\operatorname { l n }} \boldsymbol{F} \boldsymbol{D}_{\boldsymbol{t}}=\delta+\sum_{i=1}^{K} \beta_{i} \ln R_{t-i}+\sum_{j=1}^{K} \boldsymbol{\phi}_{j} \ln \boldsymbol{F} \boldsymbol{D}_{t-j}+\sum_{m=1}^{K} \Delta_{m} \ln P_{t-m}+\sum_{y=1}^{K} \lambda_{y} \ln E X_{t-y}+\sum_{Z=1}^{K} \pi_{Z} \ln C \operatorname{tax} x_{t-Z}+u_{2 t} \\
& \boldsymbol{\operatorname { l n }} \boldsymbol{P}_{\boldsymbol{t}}=\tau+\sum_{i=1}^{K} \beta_{i} \ln R_{t-i}+\sum_{j=1}^{K} \phi_{j} \ln F D_{t-j}+\sum_{m=1}^{K} \Delta_{m} \ln \boldsymbol{P}_{t-m}+\sum_{y=1}^{K} \lambda_{y} \ln E X_{t-y}+\sum_{Z=1}^{K} \pi_{z} \ln C t a x_{t-Z}+u_{3 t} \\
& \boldsymbol{\operatorname { l n } E \boldsymbol { X } _ { t }}=\psi+\sum_{i=1}^{K} \beta_{i} \ln R_{t-i}+\sum_{j=1}^{K} \phi_{j} \ln F D_{t-j}+\sum_{m=1}^{K} \Delta_{m} \ln P_{t-m}+\sum_{y=1}^{K} \lambda_{y} \ln E X_{t-y}+\sum_{Z=1}^{K} \pi_{Z} \ln C t a x_{t-Z}+u_{4 t} \\
& \operatorname{lnCtax}_{\boldsymbol{t}}=\theta+\sum_{i=1}^{K} \beta_{i} \ln R_{t-i}+\sum_{j=1}^{K} \phi_{j} \ln F D_{t-j}+\sum_{m=1}^{K} \Delta_{m} \ln P_{t-m}+\sum_{y=1}^{K} \lambda_{y} \ln E X_{t-y}+\sum_{Z=1}^{K} \pi_{Z} \ln \operatorname{Ctax} x_{t-Z}+u_{5 t}
\end{aligned}
$$


Where,

$\boldsymbol{l n} \boldsymbol{R}_{\boldsymbol{t}}=\log$ of foreign Reserve of Ireland at time $\mathrm{t}$

$\boldsymbol{I n} \boldsymbol{F} \boldsymbol{D}_{\boldsymbol{t}}=\log$ of financial development of Ireland at time $\mathrm{t}$

$\boldsymbol{\operatorname { l n }} \boldsymbol{P}_{\boldsymbol{t}}=\log$ of labor productivity of Ireland at time $\mathrm{t}$

$\ln E X_{t}=\log$ of export of Ireland at time $t$

$\operatorname{lnCtax}=\log$ of Corporate Tax in Ireland at time $\mathrm{t}$

\section{Empirical results and Discussion}

Before making VAR estimation, the research has made diagnostic estimation on the research variables. The first conducted test is stationary test or co-integration test of the variable to evaluate the existence of unit roots within the variables. This will help to identify whether there is long run relationship or not in the long. The test is made using Augmented Dickey fuller test using both intercept and trend structure of the data.

\begin{tabular}{|c|c|c|c|c|c|c|}
\hline \multirow{3}{*}{ Variables } & \multicolumn{3}{|c|}{$\operatorname{Order} I(0)$} & \multicolumn{3}{|c|}{ Order I (1) } \\
\hline & \multicolumn{2}{|c|}{ Test Statistic } & \multirow{2}{*}{\begin{tabular}{|l|} 
Interpolated Dickey- \\
Fuller 5\% Critical \\
Value \\
\end{tabular}} & \multicolumn{2}{|c|}{ Test Statistic } & \begin{tabular}{|l} 
Interpolated Dickey \\
Fuller 5\% Critical \\
Value \\
\end{tabular} \\
\hline & Intercept Only & Trend \& Intercept & & Intercept Only & Trend \& Intercept & \\
\hline \multirow{2}{*}{ In_Financial developmen } & -2.961 & & -2.969 & -6.111 & & -2.972 \\
\hline & & -2.422 & -3.556 & & -6.527 & -3.56 \\
\hline \multirow[t]{2}{*}{ In_Productivity } & -0.207 & & -2.969 & -5.946 & & -2.972 \\
\hline & & -2.607 & -3.556 & & -5.861 & -3.56 \\
\hline \multirow[t]{2}{*}{ In-Reserve } & -0.095 & & -1.95 & -5.345 & & -1.95 \\
\hline & & -1.701 & -3.556 & & -5.171 & -3.56 \\
\hline \multirow[t]{2}{*}{ In-Corporate Tax } & 0.226 & & -1.95 & -5.521 & & -1.95 \\
\hline & & -1.032 & -3.556 & & -5.462 & -3.56 \\
\hline \multirow[t]{2}{*}{ In_Export } & 7.095 & & -1.95 & -2.281 & & -1.95 \\
\hline & & -1.013 & -3.556 & & -4.952 & -3.56 \\
\hline
\end{tabular}

Table 2: Stationary Test Result, using Augmented Dickey-Fuller unit roots test

From the above table, The Augmented Dickey fuller test result indicates that all the five study variables are not stationary in their level form for both intercept and trend terms. Hence, they exhibit unit root at their level form. However, all the variables turned to become stationary after taking their first difference. Therefore, all research variables turned to become stationary and no unit root in their trend and intercept structure.

Having checked the unit root test of the variables, subsequently the research conducted lag length pre-estimation. The study found the following result using different criterion lag selection criteria. 


\begin{tabular}{|c|c|c|c|c|c|c|}
\hline Lag Length & LogL & LR & FPE & AIC & SC & HQ \\
\hline 0 & 25.17566 & NA & $2.03 \mathrm{e}-07$ & -1.222767 & -0.996023 & -1.146475 \\
1 & 188.2085 & $266.7810^{\star}$ & $4.81 \mathrm{e}-11^{\star}$ & -9.588392 & $-8.227930^{\star}$ & $-9.130638^{\star}$ \\
2 & 196.4170 & 10.94470 & $1.49 \mathrm{e}-10$ & -8.570726 & -6.076547 & -7.731511 \\
3 & 227.7564 & 32.28910 & $1.39 \mathrm{e}-10$ & -8.954934 & -5.327037 & -7.734257 \\
4 & 267.1790 & 28.67099 & $1.18 \mathrm{e}-10$ & $-9.829032^{\star}$ & -5.067417 & -8.226893 \\
\hline
\end{tabular}

Table 3: Lag length Selection criteria using AIC, SIC, FPE and HQC

Based on the alternative lag selection specifications, the majority of the selection criteria indicate that lag length (1) as appropriate and optimal choice to make the estimation. Thus, the research consider lag (1) as optimal lag length to estimate the regression.

Furthermore, to evaluate the short run and long run causality of the variables, the study conducted Johansen tests for co-integration. The estimation shows that the trace statistic is less than $5 \%$ critical value for all the parameters. In addition, the max statistic is less than $5 \%$ critical value. No equation in the model is greater than the $5 \%$ critical value. Hence, the study confirms that there is only a short run causality running among the variables within the model.

Based on Johansen tests for co-integration, the research selected VAR (Vector autoregressive model) to estimate the model.

\begin{tabular}{|r|r|r|r|r|r|}
\hline $\begin{array}{c}\text { Maximum } \\
\text { Rank }\end{array}$ & Parms & LL & eigenvalue & trace statistic & 5\% critical value \\
\hline 0 & 4 & 177.4 & - & $63.3799^{*}$ & 68.52 \\
1 & 14 & 193.09 & 0.5901 & 31.2691 & 47.21 \\
2 & 21 & 200.91 & 0.3523 & 15.6321 & 29.68 \\
3 & 26 & 206.63 & 0.2722 & 4.1931 & 15.41 \\
4 & 29 & 208.46 & 0.0965 & 0.5399 & 3.76 \\
5 & 30 & 208.73 & 0.0148 & & \\
\hline
\end{tabular}

\begin{tabular}{|r|r|r|r|r|r|}
\hline $\begin{array}{c}\text { Maximum } \\
\text { Rank }\end{array}$ & Parms & LL & eigenvalue & Max statistic & 5\% critical value \\
\hline 0 & 5 & 177.04 & - & 32.1108 & 33.46 \\
1 & 14 & 193.09 & 0.5901 & 15.6369 & 27.07 \\
2 & 21 & 200.91 & 0.3523 & 11.4391 & 20.97 \\
3 & 26 & 206.63 & 0.2722 & 3.6532 & 14.07 \\
4 & 29 & 208.46 & 0.0965 & 0.5399 & 3.76 \\
5 & 30 & 208.73 & 0.0148 & & \\
\hline
\end{tabular}

Table 4: Johansen tests for co-integration 
The estimation of Johansson test, the research found out that, the variables have only short run relationship among the variables. In this regard, the vector autoregressive regression model is suitable for the regression of the VAR equation.

\begin{tabular}{|c|c|c|c|c|c|}
\hline \multicolumn{6}{|c|}{$\begin{array}{l}\text { Vector Autoregression Estimates } \\
\text { Sample (adjusted): } 19812016 \\
\text { Included observations: } 36 \text { after adjustments } \\
\text { Standard errors in ( ) \& t-statistics in [ ] }\end{array}$} \\
\hline & LNFD & LNPRODUCTIVITY & LNRESERVE & LNCORPTAX & LNEXPORTT \\
\hline $\operatorname{LNFD}(-1)$ & $\begin{array}{r}0.768903 \\
(0.11773) \\
{[6.53107]}\end{array}$ & $\begin{array}{r}-0.083881 \\
(0.07836) \\
{[-1.07051]}\end{array}$ & $\begin{array}{r}-0.188120 \\
(0.78180) \\
{[-0.24062]}\end{array}$ & $\begin{array}{r}-0.218595 \\
(0.26534) \\
{[-0.82383]}\end{array}$ & $\begin{array}{r}0.552913 \\
(0.14502) \\
{[3.81270]}\end{array}$ \\
\hline LNPRODUCTIVITY(-1) & $\begin{array}{r}0.188475 \\
(0.21357) \\
{[0.88250]}\end{array}$ & $\begin{array}{r}0.695498 \\
(0.14214) \\
{[4.89297]}\end{array}$ & $\begin{array}{r}0.150052 \\
(1.41823) \\
{[0.10580]}\end{array}$ & $\begin{array}{r}-0.051025 \\
(0.48134) \\
{[-0.10601]}\end{array}$ & $\begin{array}{r}0.639004 \\
(0.26307) \\
{[2.42901]}\end{array}$ \\
\hline LNRESERVE(-1) & $\begin{array}{r}-0.024818 \\
(0.01816) \\
{[-1.36689]}\end{array}$ & $\begin{array}{r}0.028609 \\
(0.01208) \\
{[2.36741]}\end{array}$ & $\begin{array}{r}0.872072 \\
(0.12057) \\
{[7.23279]}\end{array}$ & $\begin{array}{r}0.110367 \\
(0.04092) \\
{[2.69700]}\end{array}$ & $\begin{array}{r}0.006593 \\
(0.02237) \\
{[0.29479]}\end{array}$ \\
\hline LNCORPTAX(-1) & $\begin{array}{r}0.071623 \\
(0.03758) \\
{[1.90571]}\end{array}$ & $\begin{array}{r}-0.049473 \\
(0.02501) \\
{[-1.97781]}\end{array}$ & $\begin{array}{r}-0.170116 \\
(0.24958) \\
{[-0.68162]}\end{array}$ & $\begin{array}{r}0.808394 \\
(0.08471) \\
{[9.54357]}\end{array}$ & $\begin{array}{r}0.042074 \\
(0.04629) \\
{[0.90883]}\end{array}$ \\
\hline LNEXPORTT(-1) & $\begin{array}{r}-0.074022 \\
(0.07387) \\
{[-1.00200]}\end{array}$ & $\begin{array}{r}0.118622 \\
(0.04917) \\
{[2.41263]}\end{array}$ & $\begin{array}{r}-0.025076 \\
(0.49057) \\
{[-0.05112]}\end{array}$ & $\begin{array}{c}0.094807 \\
(0.16650) \\
{[0.56942]}\end{array}$ & $\begin{array}{r}0.741072 \\
(0.09100) \\
{[8.14393]}\end{array}$ \\
\hline $\mathrm{C}$ & $\begin{array}{r}-0.213573 \\
(0.34436) \\
{[-0.62020]}\end{array}$ & $\begin{array}{r}0.235326 \\
(0.22919) \\
{[1.02675]}\end{array}$ & $\begin{array}{r}0.414906 \\
(2.28679) \\
{[0.18144]}\end{array}$ & $\begin{array}{r}-0.972129 \\
(0.77613) \\
{[-1.25253]}\end{array}$ & $\begin{array}{r}-0.437696 \\
(0.42418) \\
{[-1.03185]}\end{array}$ \\
\hline \multirow{10}{*}{$\begin{array}{l}\text { R-squared } \\
\text { Adj. R-squared } \\
\text { Sum sq. resids } \\
\text { S.E. equation } \\
\text { F-statistic } \\
\text { Log likelihood } \\
\text { Akaike AIC } \\
\text { Schwarz SC } \\
\text { Mean dependent } \\
\text { S.D. dependent }\end{array}$} & 0.834062 & 0.992307 & 0.764322 & 0.926472 & 0.997503 \\
\hline & 0.806406 & 0.991024 & 0.725042 & 0.914218 & 0.997087 \\
\hline & 0.082493 & 0.036542 & 3.637757 & 0.419037 & 0.125167 \\
\hline & 0.052438 & 0.034901 & 0.348222 & 0.118186 & 0.064593 \\
\hline & 30.15816 & 773.8842 & 19.45846 & 75.60176 & 2397.231 \\
\hline & 58.33235 & 72.98898 & -9.823057 & 29.07789 & 50.82748 \\
\hline & -2.907353 & -3.721610 & 0.879059 & -1.282105 & -2.490415 \\
\hline & -2.643433 & -3.457690 & 1.142979 & -1.018185 & -2.226495 \\
\hline & -0.388911 & 3.705883 & 5.783451 & 0.821480 & 6.501481 \\
\hline & 0.119179 & 0.368383 & 0.664084 & 0.403521 & 1.196831 \\
\hline \multicolumn{2}{|c|}{ Determinant resid covariance (dof adj.) } & $1.58 \mathrm{E}-11$ & & & \\
\hline & $6.33 E-12$ & & & \\
\hline \multicolumn{2}{|l|}{$\begin{array}{l}\text { Determinant resid covariance } \\
\text { Log likelihood }\end{array}$} & 208.7327 & & & \\
\hline \multicolumn{2}{|l|}{ Akaike information criterion } & -9.929597 & & & \\
\hline \multicolumn{2}{|l|}{ Schwarz criterion } & -8.609997 & & & \\
\hline
\end{tabular}

Table 5: VAR regression estimation result 
The above regression result is VAR model estimation. The estimation is made with one year time lag. The entire VAR estimation is done with 5\% significance level. Totally 36 observations are included in this VAR model.

\section{Financial development}

From the estimation result, corporate tax rate positively affects financial development in the short run. The regression shows that a one percent increases in corporate tax rate boost financial development by 7.1 percent. On the other hand, productivity, foreign reserve and export don't have statistically significant effect on financial development in the short run. Furthermore, financial development in the previous one year lag period can positively affect financial development in the next subsequent year.

\section{Productivity}

When we look at productivity in Ireland, corporate tax rate inversely affects productivity level. Corporate tax has statistically significant impact on productivity level. A one percent increase in corporate tax rate shall lead to 0.04 percent reduction in productivity in the short run. This implies that the corporate tax puts adverse effect on the productivity performance in Ireland.

The level of foreign currency reserve has statistically significant effect on the productivity performance in Ireland. This is demonstrated in the VAR estimation result; a one percent increase in the Irish foreign reserve will lead to 0.028 percent increase in productivity level.

The level of Irish export has statistically significant effect on productivity performance. A one percent increase on Irish export shall lead to 11.8 percent increase in productivity. Hence, the export has positive effect on productivity level. Nevertheless, financial development has no statically significant effect on Ireland productivity performance.

\section{Corporate tax}

When we look at corporate tax rate, Irish foreign reserve has a positive and statistically significant effect on the corporate tax rate. A one percent increase in foreign reserve shall lead increase in corporate tax rate. Both variables show positive correlation in the estimation. However, financial development, productivity and export don't have short run effect on Irish corporate tax rate.

\section{Reserve}

The VAR estimation shows that all variables, namely, financial development, productivity, export and corporate tax don't have statistically significant effect on foreign reserve of Ireland. Rather, foreign reserve in the previous one year lag can affect the subsequent year level of foreign reserve. 


\section{Export}

The VAR estimation result demonstrates that financial development is statically significant to affect export level within the Irish economy. A one percent increase in the financial development can cause export to increase by 55 percent. Likewise, productivity level can also positively affect export performance of the Irish economy in the short run. The estimation result confirms that it is statistically significant at 5 percent significance level. In this regard, a one percent increase in productivity level can cause export to increase by 63 percent. Moreover, export performance of one year lag period can significantly affect export performance in the next subsequent year. Nevertheless, corporate tax and foreign reserve don't have statistically significant effect in boosting Irish export in the short run.

\section{A. Granger causality Test}

The following table shows a granger causality test among the five variables. Granger causality shows the short run causality reinforced by one variable on the other variable within the VAR model.

\begin{tabular}{|c|c|c|c|c|}
\hline Equation & Excluded & Chi 2 & df & Prob $>$ Chi 2 \\
\hline ln_Financial development & In_Productivity & 0.934 & 1 & 0.334 \\
\hline In_Financial development & In_Resererve & 2.242 & 1 & 0.134 \\
\hline In_Financial development & ln_Corporatetax & 4.358 & 1 & 0.037 \\
\hline In_Financial development & ln_Export & 1.204 & 1 & 0.272 \\
\hline In_Financial development & All & 5.733 & 4 & 0.221 \\
\hline In_Productivity & ln_Financial Development & 1.375 & 1 & 0.241 \\
\hline In_Productivity & In_Reserve & 6.725 & 1 & 0.010 \\
\hline In_Productivity & ln_Corporatetax & 4.694 & 1 & 0.030 \\
\hline ln_Productivity & ln_Export & 6.985 & 1 & 0.008 \\
\hline In_Productivity & All & 9.8448 & 4 & 0.043 \\
\hline ln_Reserve & ln_Financial Development & 0.069 & 1 & 0.792 \\
\hline In_Reserve & In_Productivity & 0.013 & 1 & 0.908 \\
\hline In_Reserve & In_Corporatetax & 0.557 & 1 & 0.455 \\
\hline ln_Reserve & ln_Export & 0.003 & 1 & 0.955 \\
\hline In_Reserve & All & 1.700 & 4 & 0.791 \\
\hline In_Corptax & ln_Financial devlopment & 0.814 & 1 & 0.367 \\
\hline In_Corptax & In_Productivity & 0.013 & 1 & 0.908 \\
\hline In_Corptax & ln_Reserve & 8.728 & 1 & 0.003 \\
\hline ln_Corptax & ln_Export & 0.389 & 1 & 0.533 \\
\hline ln_Corptax & All & 9.765 & 4 & 0.045 \\
\hline In_Export & ln_Financial devlopment & 17.44 & 1 & 0.000 \\
\hline ln_Export & In_Productivity & 7.081 & 1 & 0.008 \\
\hline ln_Export & ln_Reserve & 0.104 & 1 & 0.747 \\
\hline ln_Export & ln_Corporatetax & 0.991 & 1 & 0.319 \\
\hline In_Export & All & 25.271 & 4 & 0.000 \\
\hline
\end{tabular}

Table 6: Granger causality Wald tests 
From the above granger causality wald test, the research found out that corporate tax rate in Ireland can granger cause financial development. On the other hand, productivity, foreign reserve and export can't unilaterally granger cause financial development in short run. Moreover, the above four variables can't jointly cause financial development in the short run.

Irish foreign reserve, corporate tax rate and export can unilaterally granger cause change in productivity level in the short run. However, financial development in Ireland can't unilaterally cause change in productivity level in the short run. Conversely, financial development, foreign reserve, corporate tax and export can jointly cause change in productivity level.

Regarding causality of the variables on foreign reserve, all the four variables, namely, financial development, productivity, corporate tax rate and export can't unilaterally cause change in the level of Ireland foreign reserve stock. Likewise, all the aforementioned variables can't cause change on the level of foreign reserve jointly.

Based on granger causality wald test, the level of foreign reserve can unilaterally cause change in the corporate tax rate in the short run. Nevertheless, financial development, productivity and export can't unilaterally cause change in the Irish corporate tax rate in the short run. Generally, however, financial development, productivity, foreign reserve and export can jointly cause change in corporate tax rate.

In the case of export, the granger causality Wald tests demonstrates that Irish financial development and productivity can unilaterally cause change in the level of Ireland export performance in the short run. On the other hand, the level of Irish foreign reserve stock and corporate tax rate can't unilaterally cause change on Ireland export performance. Nevertheless, corporate tax rate, productivity, financial development and foreign reserve can jointly cause a change on the level of Irish export performance.

\section{B. Impulse Response function}

The research has conducted the impulse response structure of the study variables on the Irish Economy.

\section{Shock (Innovation) on financial development}

Response of productivity level: A one standard deviation shock to financial development will increase productivity level until period six. After period six, the shock to financial development productivity level brings stagnant and no change on productivity performance of the Irish economy. Hence, a shock to financial development will have a positive impact on Ireland productivity performance in the short run and the impact becomes indifferent and neutral in the long run.

* Response of foreign Reserve: A one standard deviation shock to financial development initially decreases the level of Irish foreign reserve until period five. Thereafter, the response of foreign reserve towards a shock to financial development hits the steady state 
value and will remain there in the long run. Therefore, a shock to financial development will have a negative impact in the short run and the impact becomes neutral in the long run.

* Response of corporate tax: A one standard deviation shock to financial development will slightly increase the level of corporate tax rate until period five. The level of corporate tax rate will remain at steady state between periods five until period eight. However, the response of corporate tax rate will increase after period eight and goes to a positive region. Thus, a shock to financial development will have a positive impact both in short and long run.

* Response of export: A one standard deviation shock to financial development will increase export performance until period three. However, the response of export remains stagnant in the following subsequent years while remaining in the positive region. Generally, shocks on financial development will have a positive impact on Ireland export performance in the short run and long run.

\section{Shock (Innovation) on Productivity}

Response of financial development: A one standard deviation shock to productivity will increase financial development both in the short and long run and stays in the positive region. Consequently, a shock to productivity level has a positive effect on financial development

Response of Corporate tax: A one standard deviation shock to productivity will lead to increase in corporate tax rate in both the short and long run. The response remains in upward trending in the positive region. Thus, a shock to productivity level in Ireland will have positive effect on corporate tax rate.

* Response of foreign Reserve: A one standard deviation shock to productivity level can decrease the level of Irish foreign reserve. This negative response further worsens until period eleven. Based on the impulse and response simulation, during period eleven and twelve foreign reserve hits the steady state value. Thereafter, the response of foreign reserve turns to be negative and goes below the steady state level. Hence, shock to productivity will have a negative effect on foreign reserve both in the short and long run.

* Response Export: A one standard deviation shock to productivity level will consistently increase Ireland export value. The positive response steadily increases across in the positive region. As a result, a shock to productivity will have positive effect on Ireland export performance both in the short run and long run. 

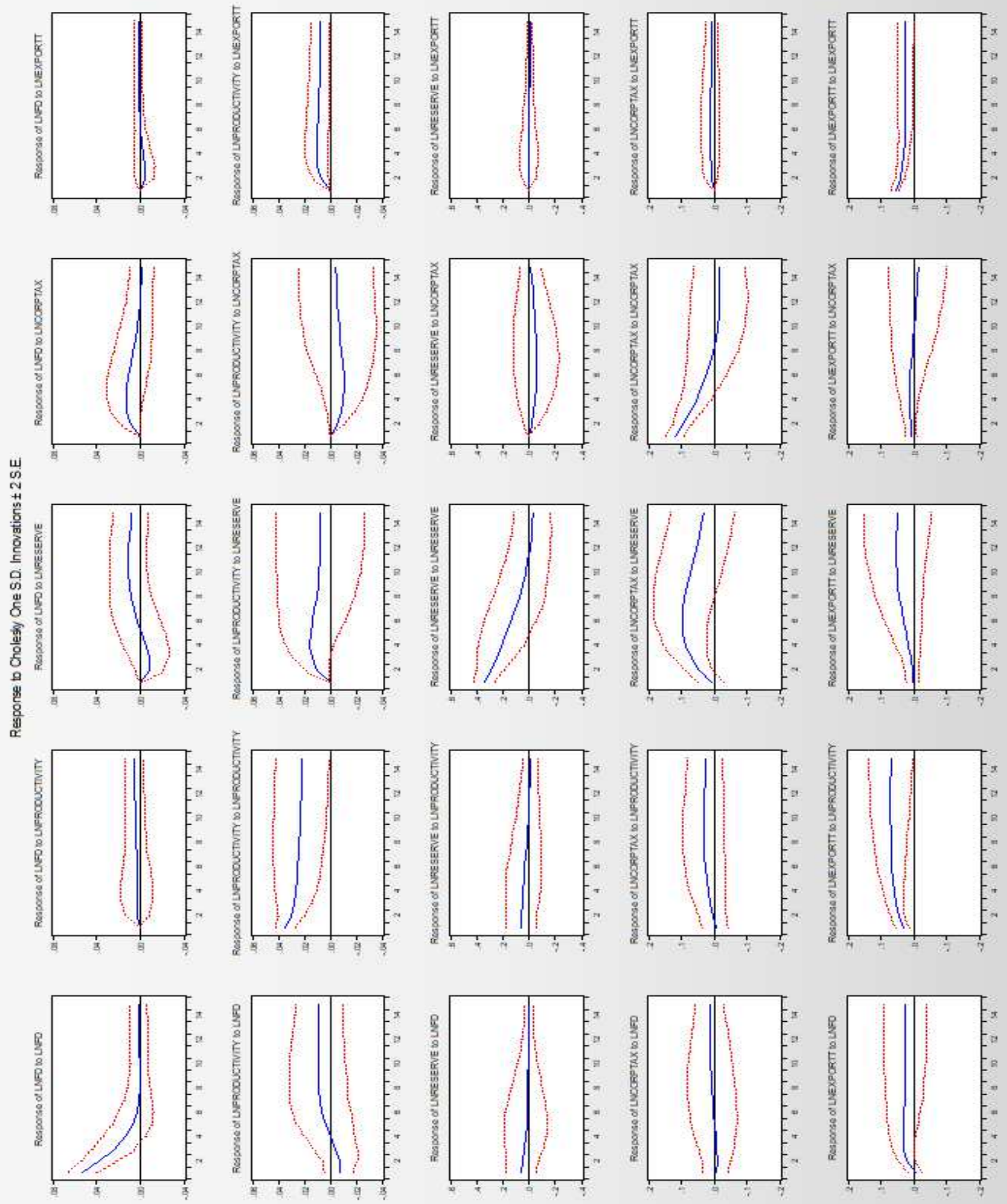

Table 7: Impulse Response Function 
Response Financial development: A one standard deviation shock to corporate tax rate will lead to increase in financial development from period one until period six. After period six, financial development responds negatively to a shock in corporate tax rate. At period 13 the financial development reaches steady state level and it goes further down to the negative region. Hence, shock to corporate tax rate will lead to increase in financial development in the short run. However, the response becomes negative in the long run.

* Response of Productivity: A one standard deviation shock to corporate tax rate will lead to sharp decline in productivity level until period six. After this period, the response of productivity will bounce back but still remains in the negative region. Therefore, shock to corporate tax rate will lead to decrease in the productivity level both in short run and long run.

* Response of foreign Reserve: A one standard deviation shock to corporate tax rate will lead to steady decline in the level of foreign reserve until period ten. Thereafter, the response of reserve level bounce back, however, it remains in the negative region below the steady state level. Hence, a shock to corporate tax rate will have a negative impact on the level of foreign reserve both in the short run and long run.

* Response of Export: A one standard deviation shock to corporate tax rate will have positive effect on export performance until period nine. From period nine to eleven, export value will hit the steady state value. After period eleven, it goes below the steady state value and the response of export gradually decline stay in the negative region. So, a shock to corporate tax rate will have a positive impact on Ireland export in the short run and negative impact in the long run.

Shock (Innovation) on foreign Reserve

Response of Financial development: A one standard deviation shock to foreign reserve will have negative effect on financial development until period six and the response remained in the negative region. After period six, the response of financial development gradually rises up and goes above the steady state value; and it remain in the positive region. Thus, a shock to foreign reserve will have a negative effect on financial development in the short run and it will finally have a positive impact on financial development in the long runs.

* Response of productivity: A one standard deviation shock to foreign reserve will have a positive effect on productivity until period four. After period four, the response of productivity becomes gradually declines but still remains in the positive region. Hence, in the short run the shock to Irish foreign reserve will have positive response on productivity level. However, the response of productivity becomes negative in the long run due to shock in reserve.

* Response of corporate tax: A one standard deviation shock to Irish foreign reserve will initially increase the level of corporate tax rate until period six. Nonetheless, after period 
six, the corporate tax rate responds negatively with a declining trend but still remains in the positive region. Therefore, shock to Irish foreign reserve will have a positive effect on the corporate tax rate in the short run. Nevertheless, in the long run shock to foreign reserve will have negative effect in the long run.

* Response of Export: A one standard deviation shock to Irish foreign reserve will steadily increase the level of export. The response of export towards a shock on foreign reserve shows consistent increase across all the time frame considered din this time period. Thus, shock to Irish foreign reserve will have positive effect on the Irish export both in the short run and long run.

Shock (Innovation) on Export

Response of financial development: A one standard deviation shock to Irish export will initially have negative impact on the financial development until period four. However, the response bounces back to the steady state level in the remaining periods. Hence, a shock to export will have a negative on impact financial development in short run. However, in the long run the impact become at steady state level.

* Response productivity: A one standard deviation shock to Irish export will initially increase the level of productivity in the economy. However, after period six, the level of productivity slightly decline but still remain in the positive region. So, a shock to export will have a positive effect on productivity in both short and long run period.

* Response of corporate tax: A one standard deviation shock to Irish export will have a slightly positive effect on corporate tax rate. However, the response of corporate tax is nearly at stagnant level but remains close to the steady state value. Hence, a shock to export will have a slightly positive effect on corporate tax both in the short and long run.

* Response of reserve: A one standard deviation shock to Irish export will have nearly neutral effect on the Irish foreign reserve. The response of foreign reserve remains in the steady state value across the different time periods. Thus, a shock to Irish export will have a neutral impact on Irish foreign reserve both in the short and long run. In other words, the shock to export doesn't have considerable impact on the foreign reserve. 


\section{Variance decomposition}

The research has conducted variance decomposition estimation for the study variables. For this research purpose, the study considers fifteen years to simulate the variance decomposition in predicting the source of the variation in the variables. The research has made the analysis both in the short run and long run scenario. The research considers up to year 3 as short run and year 15 as long run points.

\section{i. Variance decomposition of Financial development}

In the short run, impulse or shock to Irish financial development accounts 92.23 percent variation of the fluctuation in financial development (own shock). This implies that financial development is strongly endogenous. In the short run, shock to productivity can cause 0.24 percent fluctuation in financial development. Shock to foreign reserve can cause 2.76 percent variation in financial development. Impulse to corporate tax rate can cause 4.01 percent variation in financial development. Impulse to export can cause 0.742 percent variation in financial development. Therefore, productivity, foreign reserve corporate tax and export are strongly exogenous; meaning that they have weak influence in predicting financial development in short run.

In the long run, impulse or shock to financial development 77.9 percent variation of the fluctuation in financial development (own shock). This confirms that even in the long run financial development exhibit strongly endogenous nature. In the long run, impulse to productivity can cause 1.43 percent fluctuation in financial development. Shock to foreign reserve can cause 7.5 percent variation of the fluctuation in financial development. Impulse to corporate tax rate can cause 12.1 percent variation of the fluctuation in financial development. Shock to export can cause 0.94 percent fluctuation in financial development. Hence, productivity and export are strongly exogenous in predicting financial development in the long run. Nevertheless, foreign reserve and corporate tax rate are least exogenous, meaning that they have still weak influence in predicting financial development in the long run.

\begin{tabular}{|r|r|r|r|r|r|r|}
\hline \multicolumn{2}{|l|}{ Variance Decomposition of LNFD: } \\
\hline Period & S.E. & LNFD & LNPRODUCTIVITY & LNRESERVE & LNCORPTAX & LNEXPORTT \\
\hline 1 & 0.052438 & 100 & 0 & 0 & 0 & 0 \\
2 & 0.065579 & 96.49802 & 0.117917 & 1.487956 & 1.499291 & 0.396812 \\
3 & 0.071566 & 92.23444 & 0.246404 & 2.761016 & 4.01603 & 0.742114 \\
4 & 0.074406 & 88.80475 & 0.361738 & 3.205555 & 6.72073 & 0.90723 \\
5 & 0.07584 & 86.37905 & 0.475316 & 3.14973 & 9.050965 & 0.944934 \\
6 & 0.076727 & 84.57532 & 0.602614 & 3.154536 & 10.73584 & 0.931689 \\
7 & 0.077472 & 82.97988 & 0.756751 & 3.600366 & 11.74766 & 0.915344 \\
8 & 0.078241 & 81.35974 & 0.946178 & 4.573471 & 12.20759 & 0.913015 \\
9 & 0.079068 & 79.66724 & 1.172941 & 5.944717 & 12.29061 & 0.924483 \\
10 & 0.07993 & 77.96082 & 1.432665 & 7.502108 & 12.16037 & 0.944036 \\
\hline
\end{tabular}

Table 8: Variance decomposition of Financial Development 


\section{ii. Variance decomposition of Productivity}

In the short run, impulse or shock to productivity accounts 80.68 percent variation of the fluctuation in productivity (own shock). This confirms that productivity is strongly endogenous. In the short run, shock to financial development can cause 4 percent fluctuation in productivity. Likewise, shock to foreign reserve can cause 8.4 percent variation in productivity. Impulse on corporate tax rate can cause 2.9 percent variation in productivity in Ireland. Shock to export can cause 3.9 percent variation in productivity. Hence, financial development, corporate tax and export are strongly exogenous; meaning that they have weak influence in predicting productivity in the short run. Nevertheless, foreign reserve is least exogenous in predicting productivity in Ireland economy.

In the long run, which is year 10, impulse or shock to productivity accounts 67.76 percent variation of the fluctuation in productivity (own shock). The result reassures that, even in the long run productivity demonstrate strongly endogenous nature. In the long run, impulse to financial development can cause 4.82 percent fluctuation in productivity level. Shock to foreign reserve can cause 12.88 percent variation in the fluctuation of productivity. This implies that foreign reserve has least exogenous character in affecting productivity level in the long run. Impulse to corporate tax rate can cause 7.2 percent variation of the fluctuation in productivity. Moreover, shock to export can cause 7.32 percent variation of the fluctuation in productivity. Consequently, we can conclude that, financial development, corporate tax, and export are strongly exogenous in predicting fluctuation in productivity in the long run. They have weak influence in predicting productivity in Ireland in the long run. However, foreign reserve is least exogenous with having somehow slight effect in predicting fluctuation of productivity in the long run.

\begin{tabular}{|r|l|r|r|r|r|r|}
\hline \multicolumn{2}{|l|}{ Variance Decomposition of LNPRODUCTIVITY: } \\
\hline Period & S.E. & LNFD & LNPRODUCTIVITY & LNRESERVE & LNCORPTAX & LNEXPORTT \\
\hline 1 & 0.034901 & 4.239891 & 95.76011 & 0 & 0 & 0 \\
2 & 0.048074 & 5.031971 & 87.93577 & 3.970412 & 1.165494 & 1.896357 \\
3 & 0.058556 & 4.008331 & 80.68497 & 8.455785 & 2.910034 & 3.940884 \\
4 & 0.067468 & 3.02089 & 75.57681 & 11.51963 & 4.512538 & 5.37013 \\
5 & 0.075147 & 2.648122 & 72.27561 & 13.12795 & 5.717209 & 6.231108 \\
6 & 0.081803 & 2.802767 & 70.22862 & 13.73854 & 6.51161 & 6.718469 \\
7 & 0.087606 & 3.249158 & 69.00395 & 13.78319 & 6.972494 & 6.991207 \\
8 & 0.092707 & 3.798458 & 68.30487 & 13.55474 & 7.191757 & 7.150175 \\
9 & 0.097236 & 4.3413 & 67.9342 & 13.22383 & 7.248154 & 7.252518 \\
10 & 0.101306 & 4.828474 & 67.76218 & 12.88045 & 7.200673 & 7.328226 \\
\hline
\end{tabular}

Table 9: Variance decomposition of Productivity 


\section{iii. Variance decomposition of foreign Reserve}

In the short run, impulse or shock to reserve accounts 93.71 percent variation of the fluctuation in foreign reserve (own shock). This figure assures that foreign reserve is strongly endogenous. When we look the other variables, shock to financial development can cause 2.4 percent fluctuation in foreign reserve. Similarly, shock to productivity can cause 3.2 percent variation in the Irish reserve. Impulse to corporate tax rate can cause 0.61 percent variation in the fluctuation of Irish reserve, whereas, shock to export can only cause 0.0013 percent in the fluctuation of Irish reserve. Therefore, the estimation of variance decomposition shows that financial development, productivity, corporate tax, and export are strongly exogenous in predicting fluctuation in foreign reserve in the short run.

In the long run, impulse or shock to Irish foreign reserve can account 89.19 percent variation of the fluctuation in the foreign reserve (own shock). The decomposition result confirms that foreign reserve exhibit strongly endogenous nature. When we look at the remaining variables in the long run, an impulse on financial development can cause 1.95 percent in the variation of the fluctuation in foreign reserve level. Shock to productivity can cause 3.47 percent of the variation in the fluctuation of foreign reserve. Also, impulse to corporate tax can also cause 5.3 percent variation in the fluctuation of foreign reserve. In addition, shock to export can cause 0.016 percent variation in the fluctuation of foreign reserve. Thus, the result of variance decomposition indicates that financial development, productivity, corporate tax and export are strongly exogenous in predicting fluctuation Irish foreign reserve in the long run. They are weak in predicting the long run fluctuation of foreign reserve.

\begin{tabular}{|r|l|r|r|r|r|r|}
\hline \multicolumn{6}{|c|}{ Variance Decomposition of LNRESERVE: } \\
\hline Period & S.E. & LNFD & LNPRODUCTIVITY & LNRESERVE & LNCORPTAX & LNEXPORTT \\
\hline 1 & 0.348222 & 3.158376 & 2.771806 & 94.06982 & 0 \\
2 & 0.461142 & 2.723752 & 3.050226 & 94.03448 & 0.190626 & 0.000921 \\
3 & 0.529667 & 2.420832 & 3.243833 & 93.71916 & 0.614795 & 0.001384 \\
4 & 0.574229 & 2.222677 & 3.372729 & 93.17724 & 1.225738 & 0.001616 \\
5 & 0.603475 & 2.099353 & 3.452656 & 92.48663 & 1.959434 & 0.00193 \\
6 & 0.622347 & 2.026625 & 3.49549 & 91.72787 & 2.747399 & 0.002616 \\
7 & 0.634141 & 1.986572 & 3.510782 & 90.97256 & 3.526038 & 0.004047 \\
8 & 0.641218 & 1.966283 & 3.507045 & 90.27692 & 4.243116 & 0.006638 \\
9 & 0.645299 & 1.956681 & 3.492357 & 89.67848 & 4.861759 & 0.010719 \\
10 & 0.647614 & 1.951752 & 3.474293 & 89.19552 & 5.361996 & 0.016435 \\
\hline
\end{tabular}

Table 10: Variance decomposition of Reserve 


\section{iv. Variance decomposition of Corporate Tax}

In the short run, impulse or shock to corporate tax rate accounts 79.47 percent variation of the fluctuation in corporate tax (own shock). From the variance decomposition result, the magnitude confirms that corporate tax is strongly endogenous. In the short run, shock to financial development can cause 0.64 percent fluctuation in corporate tax. Impulse on productivity can cause 0.44 percent fluctuation in corporate tax. On the other hand, Shock on foreign reserve can cause 19.15 percent fluctuation in corporate tax. This result implies that Irish foreign reserve is strongly endogenous in predicting fluctuation of corporate tax rate. On the other hand, impulse on export can cause only 0.28 percent fluctuations in corporate tax rate. Therefore, from the variance decomposition result, the study concludes that financial development, productivity and export are strongly exogenous in predicting corporate tax rate in the short run.

While in the long run, impulse or shock to corporate tax can cause 32.8 percent of the variation in the fluctuation of corporate tax (own shock). The estimation shows that corporate tax rate has weakly endogenous character. In the long run, impulse on financial development can cause 0.49 percent fluctuation in corporate tax. Impulse on productivity can cause 5.32 percent fluctuation in corporate tax. Shock to export can also cause 0.84 percent fluctuation in corporate tax. Hence, financial development, productivity and export are strongly exogenous in predicting the fluctuation on Irish corporate tax. Nevertheless, impulse on Irish foreign reserve can cause 60.5 percent fluctuation in corporate tax. Foreign reserve has shown considerable increase in predicting capacity of corporate tax over the long run period. Therefore, in the long run, Irish foreign reserve is strongly endogenous in predicting corporate tax.

\begin{tabular}{|r|l|l|r|r|r|r|}
\hline \multicolumn{6}{|c|}{ Variance Decomposition of LNCORPTAX: } \\
\hline Period & S.E. & LNFD & LNPRODUCTIVITY & LNRESERVE & LNCORPTAX & LNEXPORTT \\
\hline 1 & 0.118186 & 0.308298 & 0.251557 & 0.471554 & 98.96859 & 0 \\
2 & 0.158684 & 0.581071 & 0.171515 & 7.98165 & 91.15459 & 0.111178 \\
3 & 0.189317 & 0.644737 & 0.443247 & 19.15474 & 79.47238 & 0.284901 \\
4 & 0.216171 & 0.573985 & 0.993583 & 30.54341 & 67.43772 & 0.451297 \\
5 & 0.240453 & 0.473119 & 1.704258 & 40.22683 & 57.01381 & 0.581974 \\
6 & 0.262143 & 0.400644 & 2.477633 & 47.6618 & 48.78426 & 0.675661 \\
7 & 0.28104 & 0.373396 & 3.251986 & 53.014 & 42.61971 & 0.740907 \\
8 & 0.297064 & 0.387341 & 3.993716 & 56.68052 & 38.15138 & 0.787048 \\
9 & 0.310309 & 0.431816 & 4.686484 & 59.06923 & 34.99117 & 0.821304 \\
10 & 0.321002 & 0.496034 & 5.323417 & 60.5256 & 32.80641 & 0.848533 \\
\hline
\end{tabular}

Table 11: Variance decomposition of Corporate Tax 


\section{v. Variance decomposition of Export}

In the short run, impulse or shock to Irish export accounts 43.5 percent variation of the fluctuation in export (own shock). This implies that export is weakly endogenous in predicting itself. When we look at the remaining variables, shock to financial development can cause 9.94 percent fluctuation in export. Impulse on productivity can cause 43.9 percent fluctuation on Irish export. This indicates that Irish productivity level is strongly endogenous in predicting the variation of Irish export. Shock to foreign reserve can cause only 0.78 percent fluctuations on the Irish export. And shock on the corporate tax rate can cause 1.77 percent fluctuation on the Irish export. Consequently, foreign reserve and corporate tax are strongly exogenous in forecasting the fluctuation of Ireland export performance. Conversely, productivity and financial development are endogenous in predicting the fluctuation.

In the long run, impulse or shock to export accounts 16.2 percent variation of the fluctuation in export (own shock). The decomposition result shows that the share of export has decreased considerably in the long run. This implies that export is weakly endogenous even in the long run. When we look at the remaining variables, productivity has got a lot of influence in predicting the variation of Irish export in the long run. Impulse on productivity can cause 56.8 percent fluctuation on Irish export. This indicates that productivity is strongly endogenous in forecasting the export. Impulse on financial development can cause 10.8 percent variation of the fluctuation on the Irish export. Shock on Irish foreign reserve can cause 14.9 percent fluctuation on Irish export. And shock to corporate tax rate can cause 1.09 percent fluctuation on the Irish export in the long run period. Thus, corporate tax is strongly exogenous in forecasting Ireland export performance in the long run. Conversely, financial development, foreign reserve and productivity level are strongly endogenous in the long run.

\begin{tabular}{|r|r|r|r|r|r|r|}
\hline \multicolumn{6}{|c|}{ Variance Decomposition of LNEXPORTT: } \\
\hline Period & S.E. & LNFD & LNPRODUCTIVITY & LNRESERVE & LNCORPTAX & LNEXPORTT \\
\hline 1 & 0.064593 & 0.92993 & 23.57743 & 0.172621 & 0.669139 & 74.65088 \\
2 & 0.09177 & 5.171195 & 35.93918 & 0.3321 & 1.264124 & 57.2934 \\
3 & 0.116366 & 9.9415 & 43.9127 & 0.786604 & 1.776265 & 43.58293 \\
4 & 0.139091 & 12.41522 & 49.13697 & 1.758101 & 2.06211 & 34.62761 \\
5 & 0.160286 & 13.20506 & 52.6161 & 3.347228 & 2.10314 & 28.72847 \\
6 & 0.180438 & 13.10118 & 54.82897 & 5.473859 & 1.958246 & 24.63775 \\
7 & 0.199904 & 12.60564 & 56.09852 & 7.923358 & 1.716669 & 21.6558 \\
8 & 0.21883 & 11.99157 & 56.70629 & 10.44346 & 1.459873 & 19.39881 \\
9 & 0.237203 & 11.39375 & 56.8941 & 12.82365 & 1.242525 & 17.64598 \\
10 & 0.254925 & 10.86994 & 56.84925 & 14.92898 & 1.090928 & 16.2609 \\
\hline
\end{tabular}

Table 12: Variance decomposition of Export 


\section{Conclusion}

Prior to the 1980s, Ireland financial service was underdeveloped and was regarded strange phenomenon in the country's business climate. In the 1990's, the Irish financial sector shows a dramatic growth. This was gravitated by a rapid economic growth precipitated by good domestic policies and the rising financial globalization. The global financial crisis in 2008 has put a lot of pressure on the Irish financial system. However, in the aftermath of 2008 global financial crisis, the government provides significant bailout program for Irish banks. This has helped the Irish financial systems to bounce back to its potential.

Given the significant importance of the financial development, this research is interested to evaluate the effect of Irish financial development on productivity, corporate tax, foreign reserve and export. To estimate the effect, the study collected time series data ranging from 1980 until 2016. The research has made diagnostic estimation on the research variables so as to identify appropriate econometric model for the study. The first conducted test is stationary test or cointegration test to discover the existence of unit roots within the variables. The Augmented Dickey fuller test is used both at their intercept and trend structure. At their level form, the variables exhibit unit root. Nevertheless, after taking their first difference the entire study variable become stationary. The estimation for lag length structure shows, lag (1) is the optimal lag length for the

study. To identify the co-integration structure of the variables, the study conducted Johansen tests for co-integration. Based on Johansen test, the trace statistic and max statistic is less than $5 \%$ critical value. This indicates that there is only a short run causality running among the variables within the model. Therefore, the research selected VAR model as appropriate model to estimate the impact.

Based on VAR regression result corporate tax rate positively affects financial development in the short run. On the other hand, productivity, foreign reserve and export don't have statistically significant effect on financial development in the short run. When we look at productivity, Irish corporate tax rate inversely affects productivity level. The level of foreign currency reserve has statistically significant positive effect on the productivity performance. Also, Irish export has statistically significant effect on productivity performance. When we look at corporate tax rate, Irish foreign reserve has a positive and statistically significant effect on the corporate tax rate. However, financial development, productivity and export don't have short run effect on Irish corporate tax rate.

Regarding foreign reserve, VAR estimation shows that all variables, namely; financial development, productivity, export and corporate tax don't have statistically significant effect on foreign reserve of Ireland. When we look at export, the estimation result demonstrates that financial development is statically significant to affect export level within the Irish economy. Likewise, productivity level can also positively affect export performance of the Irish export in the 
short run. Nevertheless, corporate tax and foreign reserve don't have statistically significant effect in boosting Irish export in the short run.

The study also conducted granger causality to see the short run causality among the study variables. The research found out that corporate tax rate in Ireland can granger cause financial development. On the other hand, productivity, foreign reserve and export can't unilaterally granger cause financial development in short run. Nevertheless, the above four variables can't jointly cause financial development in the short run.

On the other hand, Irish foreign reserve, corporate tax rate and export can unilaterally granger cause change in productivity level in the short run. However, financial development in Ireland can't unilaterally cause change in productivity level in the short run. Furthermore, when we look at the effect on foreign reserve all the four variables, namely, financial development, productivity, corporate tax rate and export can't unilaterally cause change in the level of Ireland foreign reserve stock

Regarding corporate tax, the level of foreign reserve can unilaterally cause change in the corporate tax rate in the short run. Nevertheless, financial development, productivity and export can't unilaterally cause change in the Irish corporate tax rate in the short run. Though, financial development, productivity, foreign reserve and export can jointly cause change in corporate tax rate.

When we look at export, Irish financial development and productivity can unilaterally cause change in the level of Ireland export performance in the short run. On the other hand, the level of Irish foreign reserve stock and corporate tax rate can't unilaterally cause change on Ireland export performance.

The research has also conducted the impulse response structure of the study variables. Shock (Innovation) on financial development will have a positive impact on Ireland productivity performance in the short run and the impact becomes indifferent and neutral in the long run. It will have a negative impact on foreign reserve in the short run and the impact becomes neutral in the long run. Also, a shock to financial development will have a positive impact on corporate tax and export performance both in short run and long run.

The Shock (Innovation) on Productivity level in Ireland can cause a positive effect on financial development, export and corporate tax rate both in the short run and long run. However, it will cause a negative effect on foreign reserve both in the short and long run.

Shock (Innovation) on corporate tax in Ireland can cause increase in financial development in the short run. However, the response becomes negative in the long run. Shock to corporate tax rate will lead to decrease in the productivity and foreign reserve level both in short run and long run. It will also cause a positive impact on Ireland export in the short run and negative impact in the long run. 
Shock (Innovation) on foreign Reserve will have a negative effect on financial development in the short run and it will finally have a positive impact on financial development in the long runs. Shock to Irish foreign reserve will have a positive effect on productivity and corporate tax rate in the short run. Nevertheless, however, the response of productivity corporate tax becomes negative in the long run due to shock in reserve. On the other hand, Shock to Irish foreign reserve will have positive effect on the Irish export both in the short run and long run.

Shock (Innovation) on Export will have a negative on impact financial development in short run. However, in the long run the impact become at steady state level. A shock to export will have a positive effect on productivity and corporate tax both short and long run period. Thus, a shock to Irish export will have a neutral impact on Irish foreign reserve both in the short and long run.

The research also conducted variance decomposition for each study variables. The variance decomposition on financial development shows in the short run financial development is strongly endogenous. Nevertheless, productivity, foreign reserve corporate tax and export are strongly exogenous. In the long run, financial development has strongly endogenous nature. But, productivity and export are strongly exogenous in predicting financial development. Nevertheless, foreign reserve and corporate tax rate are least exogenous,

The variance decomposition on productivity shows that in the short run productivity is strongly endogenous. Conversely, financial development, corporate tax and export are strongly exogenous. Nevertheless, foreign reserve is least exogenous in predicting productivity in Ireland economy. In the long run productivity demonstrates strongly endogenous nature. On the other hand, financial development, corporate tax, and export are strongly exogenous in predicting fluctuation in productivity in the long run. However, foreign reserve is least exogenous.

The variance decomposition on Irish foreign reserve shows that foreign reserve itself is strongly endogenous in the short run in predicting its own fluctuation. On the other hand, financial development, productivity, corporate tax, and export are strongly exogenous in predicting fluctuation in foreign reserve in the short run. In the long run, foreign reserve exhibit strongly endogenous nature in predicting its own fluctuation. Conversely, financial development, productivity, corporate tax and export are strongly exogenous in predicting fluctuation Irish foreign reserve in the long run.

Variance decomposition on Corporate Tax indicates that in the short run corporate tax is strongly endogenous in predicting its own fluctuation. On the contrary, financial development, productivity and export are strongly exogenous. In the long run, corporate tax rate has weakly endogenous character in predicting itself. Likewise, financial development, productivity and export are strongly exogenous in predicting the fluctuation on Irish corporate tax. Conversely, in the long run Irish foreign reserve is strongly endogenous in predicting corporate tax. 
Variance decomposition on export shows that in the short run export is weakly endogenous in predicting itself. On the other hand, foreign reserve and corporate tax are strongly exogenous in forecasting the fluctuation of Ireland export performance. Conversely, productivity and financial development are endogenous. In the long run, Irish export is weakly endogenous in predicting itself. However, financial development, foreign reserve and productivity level are strongly endogenous in the long run in predicting the Irish export fluctuation.

\section{Recommendation \& Policy Implications}

Financial sector is one of the top priority sectors to keep the economy move in its healthy trajectory. Ireland financial system has witnessed various boom and bust over the last there decades. This fluctuation has directly put a lot of pressure on the Irish economy. This research paper is conducted to evaluate the interplay among financial development, productivity, corporate tax, foreign reserve and export. These variables have different magnitude of impact on each other.

Irish monetary authorities should carefully consider corporate tax rate since it can positively affects the country's financial development as well as it can even also can cause reduction in labor productivity. Financial development is strongly endogenous in short and long run. This implies that, policy makers shall better focus on improving the pillars of financial development like enhancing financial institutions as well as its financial markets shall help to boost financial development. Nevertheless, corporate tax rate are least exogenous in affecting the fluctuation of financial development in the long run. Hence, policy makers shall use corporate tax rate as a policy tool to flourish financial development.

To further boost Irish export performance, the country need to focus on two pillars; the first one is to enhance its financial development emphasizing revamping its financial institutions as well as its financial markets. Second, productivity is strongly endogenous in forecasting the fluctuation of export sector. Hence, the country needs to engage in improvement of labor productivity, which literally helps the nation to increase its export volume and value. Furthermore, export is strongly endogenous in the short run; thus, policy instruments linked with export facilitation itself can affect its own fluctuation.

To improve Irish labor productivity, policy makers shall focus on the corporate tax rate, foreign currency reserve and export sectors. In the short run, financial development, corporate tax and export are strongly exogenous; meaning that they have weak influence in predicting productivity. However, in the long run policy instruments of these variables have considerable impact in affecting Irish productivity level. The reduction in corporate tax rate will improve Ireland labor productivity. Conversely, increasing the level of foreign reserve will help to increase the labor productivity. On the other hand, improving Irish export would also help to augment the country's productivity. 
Irish foreign reserve is highly endogenous in predicting its own fluctuation in the short run. Policy instruments using export, financial development, productivity and corporate tax are not effective tools to strengthen the foreign reserve. However, in the long run policy measures on corporate tax rate can affect foreign policy reserve. In addition, since foreign reserve is highly endogenous in the short run and long run, a policy tool that directly affects foreign reserve itself can better help to enhance the reserve stock.

Corporate tax rate is highly endogenous in the short run. Any policy measures using instruments of financial development, productivity and export may not affect corporate tax rate in the short run. Nevertheless, in the long run foreign reserve will become strongly endogenous in predicting corporate tax rate. Hence, policy makers may use controlling the level of foreign reserve so as to manipulate the rate of corporate tax in the long run. 


\section{Appendix:}

\begin{tabular}{|c|c|c|c|}
\hline \multicolumn{3}{|c|}{ Eigenvalue } & Modulus \\
\hline 0.98762 & & & 0.98762 \\
\hline 0.855492 & + & 0.1431235 & 0.867382 \\
\hline 0.855492 & - & 0.1431235 & 0.867382 \\
\hline 0.593667 & + & 0.1803192 & 0.620448 \\
\hline 0.593667 & - & 0.1803192 & 0.620448 \\
\hline
\end{tabular}

Table 13: VAR stability condition; VAR satisfies stability condition

\begin{tabular}{|c|l|l|c|}
\hline Lag & Chi2 & df & Prob > Chi 2 \\
\hline 1 & 14.7498 & 25 & 0.94704 \\
\hline
\end{tabular}

HO: no autocorrelation

Table 14: Lagrange-Multiplier Test

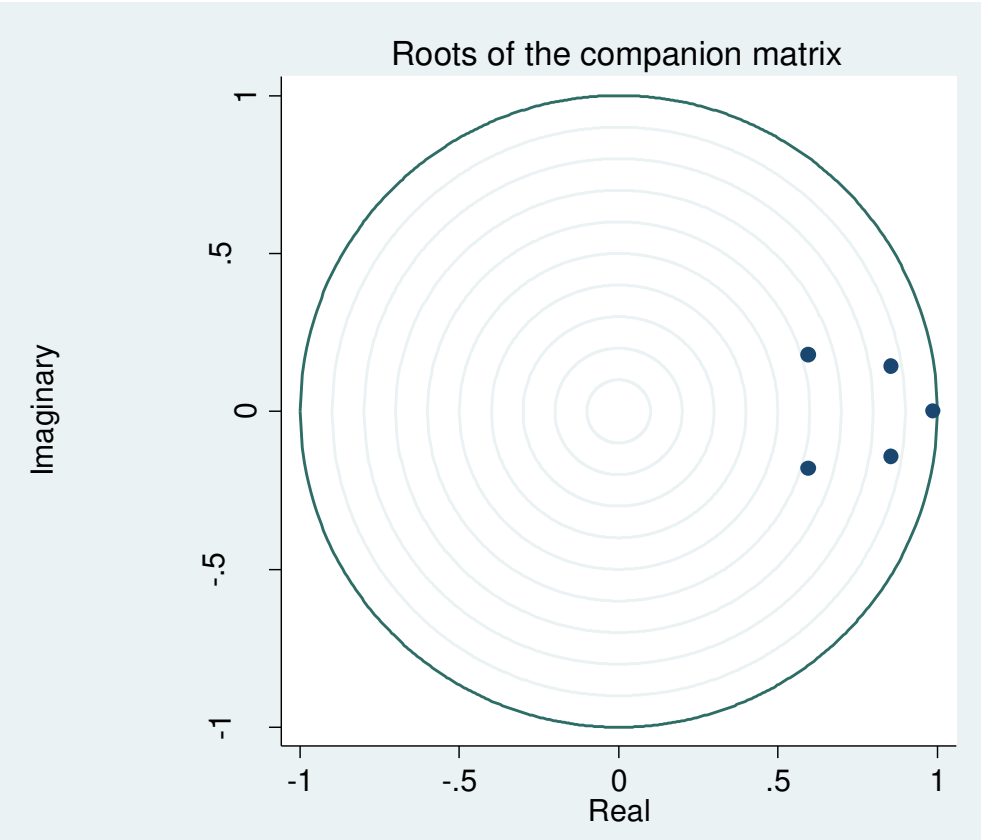

Graph 1: VAR stability Graph 


\section{Declarations}

\section{Acknowledgements}

The author wants to extend its deep gratitude for the prospective editor(s) and reviewer for their relentless effort in guiding the author towards a successful publication of this research.

\section{Authors' contributions}

The collection, processing and analysis of the data were carried out solely by the author. The author read and approved the final manuscript.

\section{Funding}

Not applicable.

\section{Availability of data and materials}

The datasets used and/or analyzed during the current study are available from the corresponding author on reasonable request.

\section{Competing interests}

The authors declare that they have no competing interests

\section{Author details}

Graduate School of Economics, Waseda University, Tokyo, Japan 


\section{Reference}

1) Daniel M'Amanja, Tim Lloyd and Oliver Morrissey (2005): Fiscal Aggregates, Aid and Growth in Kenya: A Vector Autoregressive (VAR) Analysis. Centre for Research in Economic Development and International Trade, University of Nottingham.

2) Dirk Schoenmaker (2015): Stabilizing and Healing the Irish Banking System: Policy Lessons. Ireland Lessons from its Recovery from the Bank Sovereign Loop. Dublin.

3) Eoin O'Malley (1981): 'The Decline of Irish Industry in the Nineteenth Century', Economic and Social Review, Vol. 13, No.1,

4) Eoin O'Malley (1992): 'Problems of Industrialization in Ireland', in J.H. Gold Thorpe and C.T. Whelan (eds.), the Development of Industrial Society in Ireland. Oxford University Press,

5) Eric Zivot (2000): Notes on Structural VAR Modeling

6) Frank Barry (2003): Irish Economic Development over Three Decades of EU Membership. Trinity College Dublin

7) Https://en.m.wikipedia.org/wiki/Foreign_exchange_reserve. Accessed 20 November, 2019

8) https://www.data.oecd.org/lprdty/gdp-per-hour-worked.htm. Accessed 18 November, 2019

9) https://www.worldbank.org/en/publication/gfdr/gfdr-2016/background/financialdevelopment. Accessed March 8, 2020

10) International Monetary Fund (2006): Ireland: Financial System Stability Assessment Update. IMF Country Report No. 06/292. Washington, D.C.

11) James H. Stock and Mark W. Watson (2001): 'Vector Auto regressions.' National Bureau of Economic Research, Cambridge, Massachusetts. 2001

12) Karl Whelan (2013): 'Ireland's Economic Crisis', The Good, the Bad and the Ugly, UCD Centre for Economic Research. Working Paper Series 13/06, 2013

13) Katsiaryna Svirydzenka (2016): Introducing a New Broad-based Index of Financial Development, IMF Working Paper. No. WP/16/5, 2016

14) Kieran and Petros (2018): 'How openness to trade rescued the Irish economy 'Economic and Social Research Institute, Trinity College Dublin

15) Michael Ononugbo (2015): 'Financialisation, Economy, Society and Sustainable Development' Studies In Financial Systems. No.17

16) Michael Ononugbo (2015): 'Financialisation, Economy, Society and Sustainable Development' Studies In Financial Systems. No 17

17) NESC (1996): Strategy into the 21st Century (Dublin: National Economic and Social Council) Chapter 1.

18) OECD Economic Surveys (2015): 'Ireland” September 2015. Accessed 8 December, 2019

19) Oliver Mangan (2018): The Irish Economic Update Continuing Robust Growth. Allied Irish Banks. Irish-economy-presentations

20) Patrick Honohan (2009): 'Resolving Ireland's Banking Crisis', Policy Paper. The Economic and Social Review, Vol. 40, No. 2, 2009, Trinity College Dublin and CEPR

21) Robert M. Kunst (2007): 'Vector auto regressions' 